\title{
Interdisciplinary approach to hydrological hazard mitigation and disaster response and effects of climate change on the occurrence of flood severity in central Alaska
}

\author{
Y. Y. Kontar ${ }^{1}$, U. S. Bhatt ${ }^{2}$, S. D. Lindsey ${ }^{3}$, E. W. Plumb ${ }^{4}$, and R. L. Thoman ${ }^{4}$ \\ ${ }^{1}$ Department of Geology and Geophysics, International Arctic Research Center, \\ University of Alaska Fairbanks, Fairbanks, Alaska \\ ${ }^{2}$ Department of Atmospheric Sciences, Geophysical Institute, \\ University of Alaska Fairbanks, Fairbanks, Alaska \\ ${ }^{3}$ Alaska-Pacific River Forecast Office, NOAA, Anchorage, Alaska \\ ${ }^{4}$ National Weather Service, NOAA, Fairbanks, Alaska \\ Correspondence to: Y. Y. Kontar (ykontar@alaska.edu)
}

Received: 17 April 2015 - Accepted: 17 April 2015 - Published: 11 June 2015

\begin{abstract}
In May 2013, a massive ice jam on the Yukon River caused flooding that destroyed much of the infrastructure in the Interior Alaska village of Galena and forced the long-term evacuation of nearly $70 \%$ of its residents. This case study compares the communication efforts of the out-of-state emergency response agents with those of the Alaska River Watch program, a state-operated flood preparedness and community outreach initiative. For over 50 years, the River Watch program has been fostering long-lasting, open, and reciprocal communication with flood prone communities, as well as local emergency management and tribal officials. By taking into account cultural, ethnic, and socioeconomic features of rural Alaskan communities, the River Watch program was able to establish and maintain a sense of partnership and reliable communication patterns with communities at risk. As a result, officials and residents in these communities are open to information and guidance from the River Watch during the time of a flood, and thus are poised to take prompt actions. By informing communities of existing ice conditions and flood threats on a regular basis, the River Watch provides effective mitigation efforts in terms of ice jam flood effects reduction. Although other ice jam mitigation attempts had been made throughout US and Alaskan history, the majority proved to be futile and/or cost-ineffective. Galena, along with other rural riverine Alaskan communities, has to rely primarily on disaster response and recovery strategies to withstand the shock of disasters. Significant government funds are spent on these challenging efforts and these expenses might be reduced through an improved understanding of both the physical and climatological principals behind river ice breakup and risk mitigation. This study finds that long term dialogue is critical for effective disaster response and recovery during extreme hydrological events connected to changing climate, timing of river ice breakup, and flood occurrence in rural communities of the Far North.
\end{abstract}




\section{Introduction}

Global climate change has significant effects on Alaska and its residents, both positive and negative. The warming Arctic seawaters result in an extended shipping and longer growing seasons, and thus provide new business and commerce opportunities (CFR, 2013). At the same time, quickly thawing coastal permafrost causes collapse of the shoreline, forcing many indigenous people to relocate from their communities. Moreover, the increasing loss of ice has been disrupting animal and fish migration patterns, and causing socioeconomic hardship in the region (Cozzetto et al., 2013; Moore and Huntington, 2008; West, 2011). Moreover, hydrological hazards became a bigger concern after the local population settled in permanent locations with life sustaining infrastructure and property. The goal of this paper is to illustrate via a case study how the socioeconomic wellbeing in these communities could be improved through the development of effective hydrological hazard mitigation and disaster response strategies. Sound science, appropriate policies, and effective communication should be incorporated into these interdisciplinary strategies.

\section{Background}

At the end of May 2013, several massive ice jams caused severe flooding along the Yukon River in interior Alaska. The worst flood took place in Galena, a remote village just south of the Arctic Circle. The flood did not result in fatalities or major injuries, but nevertheless caused significant suffering to Galena's residents. Within two days, the floodwaters and ice debris destroyed nearly the entire region's infrastructure (Fig. 1), and displaced over 300 residents (Andrews and DeMarban, 2013). The town lost both water and electricity, causing severe sanitation and environmental problems (ICTMN, 2013).

The overall disaster response and recovery in Galena was hampered by logistical features of the Far North. The village is located approximately 270 air miles away from the nearest large town of Fairbanks. Since Galena is not on the road system, the village can be reached only by air or river travel (Galena, 2015). The Yukon River, however, is only reliably open for boat traffic from June through September. Evacuation and subsequent disaster assistance were possible due to the fact that Galena's airport is protected by a dike that withstood the flood and kept the runway operable.

To expedite the rebuilding process and provide Galena residents with necessary life-sustaining services, President Obama issued a Major Disaster Declaration for Alaska. This authorized the Federal Emergency Management Agency (FEMA) to provide necessary assistance to the state, tribal, and non-governmental mass care partners. Since reconstruction of Galena is still underway two years later, FEMA has received much criticism (DHS, 2014).

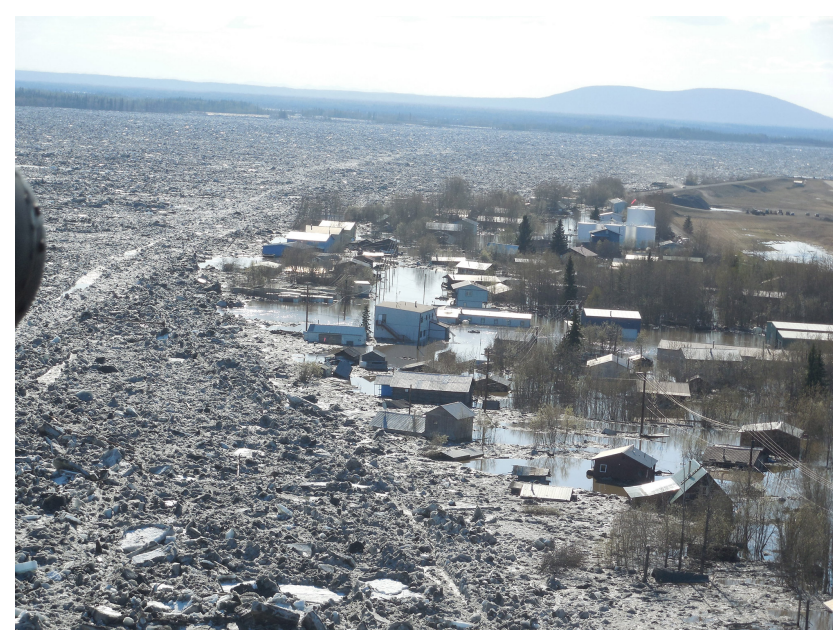

Figure 1. An aerial view shows the extent of the ice and water flooding into Galena from the Yukon River.

\section{Annual spring river ice break ups and hydrological hazard mitigation in Alaska}

In the Far North, ice jams occur on rivers during the transitional periods of freeze-up and break-up, and thus indicate the beginning and end of ice cover season (Beltaos, 2008). A combination of local and large scale factors contribute to the timing, location, and severity of ice jams, such as, river channel morphology, ice cover thickness and strength, amount of snowpack, and weather patterns (Beltaos, 2008). Although river ice breakup is the result of a balance between multiple forces, it is primarily controlled by local spring air temperatures (Bieniek et al., 2011). According to Bieniek et al. (2011), El Niño Southern Oscillation (ENSO)-related climate anomalies result in fewer storms in the Gulf of Alaska during the positive phase in springtime. This leads to reduced cloudiness over Alaska, increased downward solar radiation, which leads to warmer air temperatures and results in earlier Interior river ice breakup. Conversely, more storms occur in the Gulf of Alaska during La Niña in springtime. This leads to increased cloudiness, which leads to cooler air temperatures and results in later river ice breakup.

The extensive floods on the Yukon River in spring 2013 are attributed to abnormal weather patterns. Interior Alaska experienced the coldest April through early May on record at all long-term observations stations in 2013 (Fig. 2). As a result, the winter snowpack in the Yukon River basin persisted weeks later than normal, particularly the low elevation snowpack, and river ice remained solid and continued to increase in thickness. Then, rapid temperature warming led to the development of a classic dynamic breakup, which resulted in the formation of several massive ice jams as breakup progressed down the Yukon River.

The region where Galena is currently situated has experienced significant flooding events in 1925, 1945, 1963, 


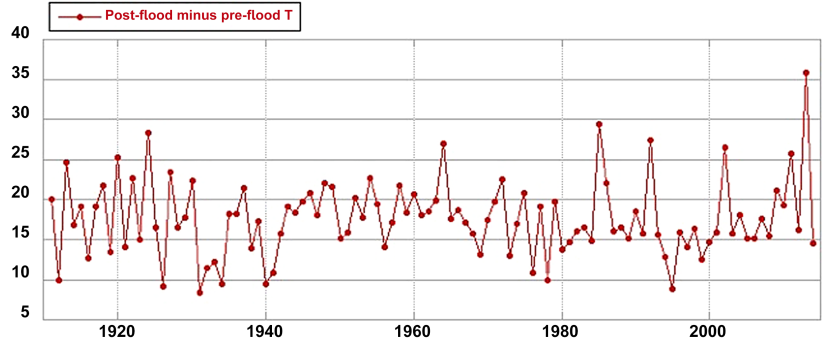

Figure 2. Temperature plot showing the post flood temperature minus the pre-flood temperature, demonstrating that Interior Alaska experienced coldest April and May in decades in 2013.

and 1971 (GSCP, 2012). Although some ice jam mitigation attempts had been made throughout US and Alaskan history, the majority proved to be futile and/or cost-ineffective (Mongin et al., 1972). According to the Alaskan Air Command report (Mongin, 1972), a dike was built around Galena Airport 1944 to accommodate a river crest of 130 feet m.s.l. (Mongin et al., 1972). The Old Town - the original native settlement, however, is located between the dike and the river, and thus has no protection from the river flooding or damaging ice floes.

In 1945 - the year following the flood, army demolition teams had tried to dislodge ice jams by placing explosive changers under the ice (Mongin et al., 1972). These efforts proved to be ineffective and therefore discontinued at the present time. After the 1971 flood, an area called New Town was constructed several miles upriver with the goal to relocate Galena residents on higher ground, further from the flood plain. Nearly $90 \%$ of the New Town infrastructure and public property was affected by the flood in May 2013.

Although it is likely that the damaging effects of ice jams can be lessened or eliminated at various sites on the Alaskan rivers, more research in the field of river ice management is needed to determine cost-effective mitigation strategies. Meanwhile, Galena along with other rural riverine Alaskan communities primarily relies on disaster preparedness, response, and recovery strategies to withstand the shock of disasters.

\section{Disaster response and recovery in Alaska: logistical and cultural challenges}

Preliminary Damage Assessments (PDAs) indicated that the 2013 flood caused a disaster of such severity and magnitude that effective response and recovery was beyond the capabilities of the State (Alaska-Flooding, 2015). A month after the flood, a major disaster was declared in Alaska. This led to collaboration between Federal, State, Tribal, and nongovernmental mass care partners to foremost provide the affected population with necessary life-sustaining services, as well as support for reunifying families. Federal disaster declaration also made Individual Assistance and Public As- sistance (including statewide Hazard Mitigation Assistance) available for the affected communities and individuals that amounted to over $\$ 80$ million (Alaska-Flooding, 2015; Andrews, 2013).

Although federal involvement brought necessary financial resources to help rebuild Galena, it also led to many frustrations. Most of valuable response time was spent on a range of paperwork and approvals. To verify the warranty of the federal disaster declaration, the agency had to conduct another set of damage assessments, thus delaying the reconstruction efforts for almost another month (Andrews, 2013). The agency also failed to implement Other Needs Assistance (ONA) policy in a timely manner (DHS, 2014). ONA provides additional financial aid to uninsured or underinsured disaster survivors who are unable to meet these needs with other means (Alaska-Flooding, 2015; DHS, 2014). Galena residents needed the ONA to help them obtain hunting and fishing gear, which are essential for their subsistence lifestyle. Failure to quickly implement ONA deprived a significant portion of Galena residents from a chance to replenish their fish and game stocks.

Federal caseworkers often appeared insensitive to local cultural aspects. FEMA neglected to take into account the cultural and historical importance that Old Town - the original settlement site, had on Galena's Native population. This and other mishaps could have been avoided if FEMA had collaborated with the Tanana Chiefs Council officials, who offered to serve as intermediaries between the agency and local tribal members (DHS, 2014).

\section{Communication during disaster response efforts in rural Arctic communities: from theories to best practices}

Insufficient communication patterns between federal, state and tribal governments, and the affected community significantly contributed to the delays in the flood response and recovery. Yet, communication is one of the most important activities in disasters (McEntire, 2007, p. 292). Effectiveness of communication depends on a variety of attitudinal and motivational characteristics of the population at risk, as well as is socioeconomic, cultural, and geographical features (Höppner et al., 2010; McEntire, 2007, 292-293).

According to the existing literature, no specific communication frameworks or tools have yet been developed in the field of natural hazards. However, Höppner et al. (2010) outline key common approaches in risk communication that could be applied to adverse events during key hazard phases. For the purposes of this case study, only culture and ethnicity approach, convergence communication approach, and social network contagion approach are analyzed below.

All in all, these approaches focus on the two-way communication that takes into account cultural, ethnic, and socioeconomic features of all stakeholders affected by the disaster 
(Höppner et al., 2010). Specifically, the culture and ethnicity approach centers on the cultural norms, as well as education level and language proficiency, in addition to household structure influence whether population at risk receives information, how they interpret it, and their subsequent response actions and time. The convergence communication approach is based on the fact that communication should be a longterm process, in which values of the risk-managing organizations and their audiences carry equal importance (Höppner et al., 2010). In this way, communication might help to anticipate and mediate potential conflict between different actors during disaster response.

Proponents of the social network contagion approach suggest that effective disaster communication is conducted through the social networks of communities (Höppner et al., 2010). In other words, rather than targeting individuals, riskmanaging agents should team up with the key social leaders of the affected communities. The underlying assumption of this approach is that people rely more on opinions from people that influence their lives on a regular basis. Therefore, by creating a liaison with community leaders, risk-managing agents would be able to establish trust with other members of the group.

The Alaska River Watch program serves as an example of successful implementation of these approaches during disasters. For over 50 years, River Watch has been conducting assessment of ice conditions throughout Alaska with the goal to provide accurate assessments of flood threats and navigational hazards (NWS, 2015). To conduct these assessments, the River Watch engages (on a volunteer basis) private and commercial pilots as well as village residents to provide their observations on the ice conditions, and thus supplement reports acquired from ground observations, aerial reconnaissance, and remote sensing.

The River Watch is managed by the National Weather Service (NWS) and supported by the State of Alaska Division of Homeland Security and Emergency Management (DHS \& EM). During the River Watch, NWS hydrologists are tasked to conduct flyovers with the DHS \& EM personnel. Scientific experts determine whether ice and river conditions are likely to cause ice jams and flooding by identifying potential locations of ice jams, flood threat, and magnitude of flooding. They also monitor water conditions if flooding is occurring, and forecast when floodwaters will recede. This information is crucial for the DHS \& EM in determining best approaches in assisting endangered communities with emergency preparedness, evacuation, and/or response.

The River Watch team also works closely with local emergency management, the community, and tribal officials by providing regular briefings on the current river, ice, or flooding conditions. They often take community leaders on flyovers to get a local perspective and knowledge of the situation. For example, during the flood in Galena in May 2013, a DHS \& EM official was on the ground assisting the community while a NWS hydrologist continued to make frequent flights over the ice jam and flooded area to determine if conditions would improve or get worse. A NWS hydrologist would also conduct regular briefings to the emergency officials and community leaders on the ground.

\section{Conclusions}

This case study underscores that communication becomes the lifeblood when managing emergency situations. It demonstrates what to do and what not to do in times of crisis in rural Alaskan regions. By strictly engaging in one-way and one-time communication efforts, FEMA largely disregarded attitudinal and motivational characteristics of Galena residents, as well as their socioeconomic and cultural traits, and geographical features of the region. As a result, they failed to stimulate desired behavior among the affected population, and postponed already delayed reconstruction efforts even further.

On the other hand, the Alaska River Watch program has been fostering a long-term dialogue with the local emergency management, tribal officials, and residents of rural Alaska communities. As a result, they were able to establish and maintain a sense of partnership as well as trustful and reliable communication patterns between multiple disaster actors. Due to their efforts in developing long-lasting, open, and reciprocal communication with the community, the River Watch program is able to provide information and guidance to local officials and residents so they can take prompt actions.

In addition to establishing and fostering effective communication with emergency state agents and affected communities, the Alaska River Watch program provides flood forecasting and warnings as necessary precautionary measures. As a flood preparedness and community outreach program, the River Watch provides effective mitigation efforts in terms of ice jam flood effects reduction by informing the community of existing ice conditions and flood threats. This is the only cost-effective and proactive ice jam mitigation effort that currently exists in Alaska. More research in the field of river ice management is needed to determine the potential effectiveness of other ice jam mitigation strategies. Meanwhile, Galena, along with other rural riverine Alaskan communities, has to mostly rely on disaster preparedness, response, and recovery strategies to withstand the shock of disasters. 


\section{References}

Alaska-Flooding: Alaska - Flooding, FEMA-4122DR, http://www.fema.gov/media-library-data/ 20130726-1923-25045-7833/dhs_ocfopdareport_ fema4122drak.pdf, last access: February 2015.

Andrews, L.: Hard lessons for FEMA: Galena rebuilds with federal help, in spite of federal help, Alaska Dispatch News, http://www.adn.com/article/20130920/ hard-lessons-fema-galena-rebuilds-federal-help-spite-federal-help (last access: March 2015), 20 September 2013.

Andrews, L. and DeMarban, A.: Rescue aircraft evacuating more Galena residents as flooding worsens, http://www.adn.com/article/20130528/ rescue-aircraft-evacuating-more-galena-residents-flooding-worsens, (last access: 15 February 2015), 2013.

Beltaos, S.: Progress in the study and management of river ice jams, Cold Reg. Sci. Technol., 51, 2-19, doi:10.1016/j.coldregions.2007.09.001, 2008.

Bieniek, P. A., Bhatt, U. S., Rundquist, L. A., Lindsey, S. D., Zhang, X., and Thoman, R. L.: Large-Scale Climate Controls of Interior Alaska River Ice Breakup, J. Climate, 24, 286-297, doi:10.1175/2010JCLI3809.1, 2011.

CFR - Council on Foreign Relations: The Thawing Arctic: Risks and Opportunities, http://www.cfr.org/arctic/ thawing-arctic-risks-opportunities/p32082 (last access: March 2015), 2013.

Cozzetto, K., Chief, K., Dittmer, K., Brubaker, M., Gough, R., Souza, K., Ettawageshik, F., Wotkyns, S., Opitz-Stapleton, S., Duren, S., and Chavan, P.: Climate change impacts on the water resources of American Indians and Alaska Natives in the U.S., Climatic Change, 120, 569-584, 2013.
DHS: Department of Homeland Security Office of Inspector General, FEMA's Response to the Disaster in Galena, Alaska, http://www.oig.dhs.gov/assets/GrantReports/2014/OIG_ 14-106-DJun14.pdf (last access: February 2015), 2014.

Galena: Get to know Galena, http://www.ci. galena.ak.us/index.asp?Type=B_DIR\&SEC= 65705C55-D746-4B9C-B966-9D0F84FC742D, last access: February 2015.

GSCP - Galena Strategic Community Plan, ftp://www.aidea.org/ REFund/Round_7/Applications/1047_Galena_Community_ Wood_Heat_Project/8._Galena_StrategicCommunityPlan_Intro. pdf (last access: February 2015), 2012.

Höppner, C., Bruündl, M., and Buchecker, M.: Risk Communication and Natural Hazards, CapHaz-Net WP5 Report, Swiss Federal Research Institute WSL, http://caphaznet.org/ outcomes-results/CapHaz-Net_WP5Risk-Communication.pdf (last access: February 2015), 2010.

ICTMN - Indian Country Today Media Network: Galena, Alaska Struggles to Rebuild After Yukon River Ice Jam Causes Devastating Flood, http://indiancountrytodaymedianetwork.com (last access: February 2015), 2013.

McEntire, D.: Disaster Response and Recovery, John Wiley \& Sons, Inc., Hoboken, NJ, 2007.

Mongin, A., Mesloh, D. E., and Beck, P. L.: History of Alaskan Air Command, 1 July 1970-30 June 1972, 1972.

Moore, S. E. and Huntington, H. P.: Arctic Marine Mammals and Climate Change: Impacts and Resilience, Ecol. Appl., 18, S157S165, doi:10.1890/06-0571.1, 2008.

NWS - National Weather Service Alaska-Pacific River Forecast Center: River Watch Program, http://aprfc.arh.noaa.gov/ rivwatch.php, last access: March 2015.

West, C. T.: The Survey of Living Conditions in the Arctic (SLiCA): A Comparative Sustainable Livelihoods Assessment, Environ. Develop. Sustain., 13, 217-235, 2011. 